пропедевтичного курсу функціонального аналізу визначено професійно спрямовані вміння, які доцільно формувати в цьому курсі.

\title{
Література
}

1. Абакумова С. И. Профессиональная направленность преподавания математики в инженерно-техническом вузе [Текст] / Абакумова С. И. // Вестник Университета Российской Академии Образования. - 2009. - № 1. - С. 156-158. 2. Батышев С. Я. Подготовка рабочих в средних профессионально-технических училищах / С. Я. Батышев. - Москва : Педагогика, 1988. - 176 с. 3. Бочкарева О. В. Профессиональная направленность обучения математике студентов инженерно-строительных специальностей вуза : дисс. на соискание ученой степени канд. пед. наук : 13.00.02 / О. В. Бочкарева. - Пенза, 2006. - 150 с. 4. Волянська О. $\mathbf{Є}$. Вивчення алгебри і початків аналізу в професійно-технічних училищах в умовах впровадження освітнього стандарту : автореф. дис. на здобуття наукового ступеня канд. пед. наук : спец. 13.00.02 «Теорія та методика навчання (математика)»/ О. Є. Волянська / Національний педагогічний ун-т імені М. П. Драгоманова. - Київ, 1999. 18 с. 5. Козловська I. М. Теоретичні та методичні основи інтеграції знань учнів професійнотехнічної школи : дис. на здобуття наук. ступеня д-ра пед. наук : 13.00 .04 / Козловська I. М. / АПН України; Інститут педагогіки і психології професійної освіти. - Київ, 2001. - 464 с. 6. Носков М. Компетентностный подход к обучению математике [Текст] / М. Носков, В. Шершнева // Высшее образование в России : Научно-педагогический журнал. - 2005. № 4. - С. 36-39.

\section{РОЗРОБЛЕННЯ ТА ВПРОВАДЖЕННЯ ПРЕДМЕТНИХ І МІЖПРЕДМЕТНИХ ПРОГРАМНО-ДИДАКТИЧНИХ КОМПЛЕКСІВ ТА АКТИВАЦІЯ ПРОЦЕСІВ МОТИВАЦІЇ ПІЗНАВАЛЬНОЇ ДІЯЛЬНОСТІ СТУДЕНТІВ ЯК СКЛАДНИКИ ДИДАКТИЧНОЇ ІНТЕНСИФІКАЦІЇ НАВЧАЛЬНОЇ ДІЯЛЬНОСТІ}

Малихіна С. В. Розроблення та впровадження предметних i міжпредметних програмно-дидактичних комплексів та активація процесів мотивації пізнавальної діяльності студентів як складники дидактичної інтенсифікації навчальної діяльності.

У статті обгрунтовано деякі із субпідрядних дидактичних умов дидактичної інтенсифікації навчальної діяльності студентів. Визначено шляхи здійснення дидактичної інтенсифікації, дидактичні умови дидактичної інтенсифікації як певні вимоги, що покликані забезпечити її гарантовану результативність.

Ключові слова: дидактична інтенсифікація, навчальна діяльність студентів, дидактичні умови, шляхи здійснення дидактичної інтенсифікації, система дидактичних умов.

Малыхина С. В. Разработка и внедрение предметных и межпредметных программнодидактических комплексов и активация процессов мотивации познавательной деятельности студентов как составляющие дидактической интенсификации учебной деятельности.

В статье обосновываются некоторые субподрядные дидактические условия дидактической интенсификации учебной деятельности студентов. Определены пути осуществления дидактической интенсификации, дидактические условия дидактической интенсификации как определенные требования, призванные обеспечить ее гарантированную результативность. 
Ключевые слова: дидактическая интенсификация, учебная деятельность студентов, дидактические условия, пути осуществления дидактической интенсификации, система дидактических условий.

Malykhina S. V. Development and implementation of subject and intersubject curriculum and didactic packages and activation of motivation processes of students' cognitive activity as parts of a didactic intensification of educational activity.

The article explains some minor didactic conditions of students' educational activities didactic intensification. The ways of didactic intensification implementation, its didactic conditions as certain requirements to ensure its guaranteed performance have been determined.

Key words: didactic intensification, students' educational activities, didactic conditions, ways of didactic intensification, system of didactic conditions.

3 розвитком науки, утвердженням в освітній системі нових інформаційноінноваційних технологій, збільшенням обсягу доступної для студента інформації, потребою «продукування інтелектуального багатства» (А. Кузьмінський [4, с. 189]) пов’язується інтелектуалізація економічного та суспільного життя. Сьогодні не лише зростає роль освіти й науки загалом, а й значення власне інтелектуальної діяльності для багатьох економічних галузей, які раніше розвивалися екстенсивно. Такі тенденції сприяють формуванню та вдосконаленню науково-професійного освітнього потенціалу і $є$ важливими чинниками соціально-економічного розвитку суспільства. Щодо сучасного виробництва, то всі його учасники повинні бути не лише кваліфікованими користувачами технічних устаткувань i технологій, які неперервно оновлюються та вдосконалюються, а й постійно брати участь у цих удосконаленнях та новаціях, здійснювати пошук принципово нових, результативних технічних, організаційно-технічних рішень. Тож саме за період навчання у вищому навчальному закладі студент - майбутній фахівець повинен призвичаїтись до інтенсифікації власної (на той момент - навчальної) діяльності.

Результативність інтенсифікаційних процесів безпосередньо залежить від низки дидактичних умов. 3 цієї позиції доцільно розглянути особливості супідрядних дидактичних умов інтенсифікації навчальної діяльності студентів, що і становить мету цієї статmі.

Одна 3 супідрядних дидактичних умов інтенсифікації навчальної діяльності студентів - планомірне й поступове здійснення інтенсифікації змісту навчальної діяльності шляхом розроблення та впровадження предметних і міжпредметних програмно-дидактичних комплексів, що базуються на інноваційних інформаційно-комунікаційних технологіях навчання.

Проектування та реалізація в навчальному процесі предметних та міжпредметних програмно-дидактичних комплексів, заснованих на сучасних комп’ютерних та інформаційно-телекомунікаційних технологіях в сучасних реаліях вищої школи $\epsilon$ оптимальним шляхом реалізації завдань дидактичної інтенсифікації навчальної діяльності.

Програмно-дидактичний комплекс - сукупність програмно-методичного забезпечення навчальних дисциплін та сучасного комп’ютерно-програмного супроводу. Закономірно, що поступовий розвиток нових технологій (мультимедійні, гіпертекстові, мережеві, телекомунікаційні), їх входження у сферу вищої освіти спричинили появу нових напрямів науково-педагогічних досліджень, вислідом яких є CAI Computer-Assisted Instruction навчання за допомогою комп’ютера, CAL Computer-Assisted Learning - вивчення за допомогою комп’ютера, CAT Computer-Assisted Teaching- викладання за допомогою 
комп'ютера, CBE Computer-Based Education - освіта на основі комп’ютерних технологій, CML Computer-Managed Learning - навчання під керівництвом комп’ютера (I. Костікова, I. Кожемяко [3]).

Сучасний комп’ютерно-інформаційний простір несе нові культурні норми, нові ментальні стереотипи та життєві навички; культура віртуальної реальності вирізняється глобальними масштабами свого поширення і впливу на всі сфери й устрій суспільного життя, індивідуального буття особистості. М. Кастельс пояснює це тим, що нова комунікаційна система радикально трансформує простір і час. Можливості сучасного інформаційно-комунікаційного середовища в межах мережі Internet та віртуальний простір загалом інколи порівнюють з великими географічними відкриттями, які сприяли зближенню народів і культур. Очевидно, що комп’ютерно-віртуальна реальність повинна визначати зміст і сенс дидактичної інтенсифікації навчальної діяльності сучасних студентів. Вона значною мірою активізує інтелектуальну діяльність, змушує шукати альтернативні варіанти і звільняє свідомість від сталих стереотипів. Сучасні студенти вищого навчального закладу це покоління, яке виросло в тісному спілкуванні з комп’ютерами, віртуальними іграми, мобільним зв'язком, саме сформованість цих умінь варто брати до уваги, добираючи засоби дидактичної інтенсифікації. До того ж мова повинна йти не тільки про навички роботи 3 сучасною комп’ютерною технікою, а й про «зміни фундаментальних духовно-культурних структур, понять і уявлень: інакше організовується внутрішній світ особистості, а інтелектуальні та творчі здібності розвиваються не просто швидкими темпами, вони стають різнобічнішими, застосовуються в іншому соціально-культурному вимірі.

У навчальній діяльності сучасні студенти користуються можливістю здійснювати пошук необхідної навчальної інформації в національних бібліотеках світу, доступних архівах і фондах, у ході віртуальних екскурсій ознайомлюються з колекціями музеїв різних країн та здійснюють детальне їх вивчення, розширюється коло особистих знайомств, створено можливості для іншомовної комунікативної практики тощо. Моделювання когнітивної реальності засобами когнітивної графіки створює нове уявлення про картину світу, альтернативні форми і шляхи розвитку ситуацій, явищ, процесів. Комп’ютерне моделювання стимулює художню творчість, породжуючи нові асоціації і фантастичні образи, розвиває уявлення й фантазію, які конче необхідні не лише для студентів так званих творчих спеціальностей.

Окремою галуззю дидактики вищої школи є дистанційне навчання. Зараз воно визнане як новітня форма освіти, ми ж ведемо мову про використання дистанційності в умовах реального вищого навчального закладу. Дослідженню проблем дистанційного навчання приділяється належна увага в зарубіжних педагогічних дослідженнях: вивчають проблеми сучасного стану та перспективи розвитку дистанційної освіти Дж. Андерсон, Ст. Віллер, Д. Крем; праці, наукові праці, присвячені педагогічному та дистанційному навчанню публікують О. Кириченко, Дж. Мюллер, Н. Морозе, Н. Мясоєдова, Є. Полат та ін. Нові педагогічні підходи до комп’ютеризації навчального процесу розробляють Б. Гершунський, І. Підласий, О. Рибалко, різні аспекти дистанційного навчання та навчання за допомогою телекомунікаційних засобів висвітлюють у своїх роботах Т. Назарова, Г. Онкович та інші. Розробляються методики on-line-лекції, on-line-консультування (групового та індивідуального).

Планомірне й поступове здійснення інтенсифікації змісту навчальної діяльності реалізується через:

- використання системних мультимедійних технологій із застосуванням аудіо- та 
відеотехніки, системних накопичувачів, що використовуються для моделювальних, імітувальних, графічно-віртуальних навчальних дій;

- «інтелектуальні навчальні експертні системи, специфіковані за конкретними галузями застосування» [2, с. 29], що мають прикладне значення в навчальній та навчальнодослідницькій діяльності студентів;

- інформаційні середовища та оболонки, що забезпечують прямий та віддалений доступ до інформаційних ресурсів навчальних закладів, автоматизованих сховищ поновлюваної інформації, відповідають процесам роботи в сучасних освітньо-технологічних умовах та в певній професійній діяльності;

- телекомунікаційні системи (здійснюється забезпечення телеконференцій, віртуальне слідкування, «відео-мости», себто можливість виходу в глобальні мережі та реалізація навчальних, навчально-інформативних, комунікативних функцій освіти);

- можливість швидкого й ефективного доступу до світових інформаційних ресурсів.

Сучасний комп’ютерно-програмний супровід якісно змінює діяльності викладання та учіння. Водночас постають проблеми постійного та безперервного вдосконалення методик викладання окремих дисциплін та їхньої інтеграції на грунті використання інформаційнокомунікаційних технологій.

Проектування й реалізація в навчальному процесі професійно спрямованих предметних та міжпредметних програмно-дидактичних комплексів, заснованих на комп’ютерних та телекомунікаційних технологіях, здатне якісно змінити сутність навчальної діяльності студентів. У роботах Г. Онкович, Г. Селевко розглядаються основні принципи розроблення таких комплексів, підкреслюється, що мультимедійність не є лише засобом навчання. Результати досліджень вітчизняних та зарубіжних наковців, у тому числі, - в межах міжнародних освітніх проектів DELTA і TEMPUS дозволяють зробити висновок про те, що всі проекти впровадження в навчальне середовище мультимедіа мають високий інтенсифікаційно-освітній потенціал. Однак саме в цьому аспекті практика використання мультимедіа в навчальному процесі значно випереджає рівень теоретичного осмислення новітніх тенденцій.

Сучасні студенти в повсякденній навчальній діяльності, як правило, використовують ноутбуки, нетбуки, планшетні пристрої, комунікатори. Освітні системи насичуються новітньою інформаційною продукцією, використовуються новітні мультимедійні технології - себто засоби навчання, що містять у своїй структурі різні види інформації: у вигляді текстів, аудіо-, відео-, анімаційних елементів (наприклад, мультимедійні дошки). Мультимедійна обізнаність є необхідним елементом застосування сучасних інформаційних технологій у вищій школі.

Провідний авторитет у галузі засобів інформації Н. Постман чітко схарактеризував ментальний розрив між «мультимедійним» та «друкарським» мисленням: у той час як друковане слово сприяє систематичному викладу, телебачення краще пристосоване до невимушеної розмови. Підкреслимо різницю його словами: «Друковане слово має сильну пристрасть до пояснення; воно вимагає витонченої здатності мислити концептуально, дедуктивно i послідовно, високої оцінки причини i наслідків, неприпустимості суперечностей, розвинутої здатності до неупередженості та об’єктивності, терпимості до сповільненої реакції» [6, с. 87].

Деякі дослідники звертають увагу на ризики, які мають місце в тотальній комп’ютеризації навчальної діяльності студентів. Це ризики віртуалізації та дегуманізації свідомості суб’єктів навчальної діяльності: в силу єдності внутрішнього та зовнішнього 
планів навчальної діяльності ставлення до віртуальних об’єктів і оцінці дій 3 ними, сформоване в процесі діяльності в навчальному віртуальному просторі може підміняти собою ставлення до реальних об’єктів і оцінці дій в реальному світі, викривляючи процеси соціалізації особистості. Комп’ютерно-інформаційний простір (сервер баз даних, інформаційна система тощо) працює на логічній основі, зберігає і передає інформацію в знакових формах без зіставлення з чуттєво-емоційною сферою, поза емоціями та етичними нормами. Зберегти гуманістичну спрямованість сучасної особистісно зорієнтованої вищої освіти та уникнути сурогатності взаємодії в системах «комп’ютер-студент», «віртуальний навчальний простір - студент», опосередкованої інформаційно-комп’ютерними технологіями, можливо саме у процесі дидактичної інтенсифікації навчальної діяльності.

Український дидакт Г. Атанов цілком правомірно вказує: «Нині створена велика кількість різноманітних програм навчального призначення, однак, як свідчить практика, суттєвого впливу на навчальний процес вони майже не здійснюють. Комп’ютер у навчанні використовується переважно так само, як і традиційні засоби навчання. Наголос у більшості програм, що використовуються, робиться на наочність, яка за допомогою комп’ютера реалізується, зрозуміло, дуже ефективно. Однак, часто це тим і обмежується, оскільки програми по суті $є$ демонстраційними. Основним змістом навчальних систем залишаються знання, а діяльності з обробки цих знань відводиться другорядна роль, як правило, ілюстративна» [1, с. 32]. Ми намагалися ліквідувати вказаний недолік, тому методичний інструментарій інтенсифікації навчальної діяльності студентів передбачає:

а) розроблення електронних навчальних посібників, що включають тексти, які містять професійно значущу інформацію, необхідну для підготовки фахівців певного профілю, електронний лекційний курс; система різнорівневих проблемних, проблемно-пошукових самостійно-пізнавальних завдань;

б) застосування програми різнорівневої професійно орієнтованої НД студентів 3 переробки інформації (на кшталт Веб-квестів);

в) ресурси програмованого контролю: комп’ютерні тести діагностики рівня засвоєння навчальної інформації, тести та завдання для самоконтролю та самооцінки рівня сформованості самостійно-пізнавальної діяльності, інформаційно-методичне забезпечення програм підсумкового контролю за допомогою комп’ютера;

г) комп’ютерні методичні посібники, що містять рекомендації викладачам щодо ефективного управління професійно зорієнтованою самостійною пізнавальною діяльністю студентів;

д) засоби індивідуального та групового консультування on-line;

е) фонд комп’ютерних сертифікованих програм за різними напрямами професійної підготовки студентів з циклу економічних дисциплін.

Інша супідрядна дидактична умова інтенсифікації навчальної діяльності студентів активація процесів мотивації пізнавальної діяльності студентів шляхом впливу на механізми самоорганізації, саморегуляції й самовдосконалення.

Сучасні тенденції у вищій освіті пов’язані 3 активізацією інтелектуальної, пізнавальної діяльності студентів, яка сприяє формуванню та розвитку таких якостей фахівця, як здатність бачити, ставити і розв’язувати професійні проблеми, приймати оптимальні рішення в умовах багатофакторності i дефіциту часу, вміння бачити i враховувати, тобто розуміти численні сенси в галузі своєї діяльності та в суміжних галузях. Тому активізація мотивації пізнавальної діяльності студентів у руслі здійснення дидактичної інтенсифікації - не самоціль, а умова, що забезпечує формування професійних якостей 
фахівця на сучасному етапі розвитку суспільства.

Дидакти вищої школи підкреслюють, що «свідоме учіння зумовлюється передусім рівнем сформованості мотивів навчання, розумінням практичної цінності й потреби в знаннях для обраної професійної діяльності» [4, с. 224]. Процес навчання як процес цілеспрямованої, доцільної діяльності пов’язаний з потребами, мотивами, постановкою цілей, плануванням, підготовкою до здійснення діяльності. 3 психологічних джерел відомо, що навчальна мотивація є різновидом мотивації, включеної до діяльності учіння. Навчальна мотивація характеризується такими ознаками, як спрямованість, стійкість, динаміка (А. Бугріменко). Суб’єкт навчальної діяльності здатен сам висунути мету діяльності, керуючись певними потребами та цільовими настановами. Зазначимо: численні дослідження мотивації навчальної діяльності на рівні загальноосвітніх закладів та на рівні вищих навчальних закладів (В. Вілюнас, М. Гамезо, Є. Ільїн, С. Рубінштейн та інші) мають своїм наслідком опис типів мотивів навчальної діяльності, опис груп навчальних мотивів. Психолог М. Гамезо пропонує розрізняти дві великі групи мотивів навчальної діяльності:

а) мотиви пізнавальні;

б) мотиви соціальні.

У дослідженнях сучасних українських психологів вищої школи (Л. Подоляк, В. Юрченко) до цього переліку додається окрема група мотивів, пов’язаних з особливостями майбутньої професійної діяльності студента. До соціальних мотивів належать:

- широкі соціальні мотиви, що полягають у прагненні отримати знання на основі усвідомлення соціальної необхідності, усвідомлення зобов’язань, відповідальності, корисності суспільству, родині тощо;

- вузькі соціальні або позиційні мотиви, що полягають у прагненні зайняти певну позицію, посісти певне місце в стосунках 3 навколишніми, заслужити авторитет; виявляються у прагненні взаємодії та контактах з оточуючими, зверненнях до товаришів під час навчання, намаганнях з'ясувати ставлення інших до себе та своєї діяльності, ініціативності та безкорисливості [5, с. 298].

Психологи зазначають, що такі концепції мотивації розрізняються не лише теоретичними та термінологічними настановами, а й тим, що саме в них є об'єктом дослідження, тому в думках про те, що в основі мотиваційної сфери людини є її соціальна активність. Аналіз наукової психологічної літератури дозволяє окреслити певну «зону узгодження», а також коло питань, щодо яких існує розширене тлумачення окрім центрального, загальновизнаного феномену. Переважно до мотивації відносять усе те, що збуджує реально здійснювану активність: узагальнені та більш конкретні цілі, заради яких індивід навчається, досягненню яких він присвячує своє життя (В. Вілюнас, Є. Ільїн).

Пізнавальна мотивація виникає, внаслідок «продуктивного нерозуміння» (I. Кудрявцев, С. Кулюткін). Оскільки нерозуміння виникає через суперечливість нових знань (фактів, явища тощо) щодо системи уявлень, яка вже склалася в суб’єкта, то причиною нерозуміння 3 очевидністю виступають суперечності пізнання. Суперечність як ядро діалектики є в такому випадку рушієм мислення; а нерозуміння - психологічним втіленням цієї суперечності. У такому («продуктивному») нерозумінні виражається діалектика пізнання - від нерозуміння до часткового розуміння і відносно повного розуміння. Та викладачі з багаторічним досвідом педагогічної діяльності у вищих навчальних закладах добре знають: далеко не кожне студентське «нерозуміння» надає поштовх до активації мисленнєвої, пізнавальної діяльності (звідси - помилки, упередження тощо). Дослідники в такому випадку ведуть мову про «непродуктивне» нерозуміння: суперечності не долаються, 
а знімаються різними, доступними розумінню студента, способами: нові дані, нова інформація розуміються як помилкові, усунута суперечність у такому разі призводить до нових помилок, до нерозуміння сутності явищ, суб’єкт пізнання ігнорує суперечності, вплітає нові факти в стару систему, студент бачить невідповідність, та не може сформулювати проблему, потрапляючи у безвихідну ситуацію. I психологи, і дидакти вищої школи констатують: найчастіше такі випадки у практиці вищої школи пов’язані з невмінням студентів застосовувати теоретичні знання (тобто зрозуміти і осмислити інформацію) у професійній діяльності; або при загальній успішній професійній діяльності (наприклад, під час виробничої практики) - невміння пояснити ії̈ теоретичну сутність. Така неузгодженість у прагматичному плані також серйозно шкодить якості підготовки майбутнього фахівця, оскільки обмежує його професійний кругозір, творчі можливості тощо. Сучасні психологи, дидакти, зацікавлені як у розкритті причин нерозуміння, мотивів навчально-пізнавальної діяльності, так і у розкритті її причин, визначенні способів дидактичного впливу на здатність студента ефективно здійснювати навчальну діяльність.

У зв’язку зі сказаним вище, доволі цікавими видаються науково-теоретичні дослідження, здійснені на межі психології та дидактики вищої школи. Так, Є. Ізотова, вивчаючи психологічну структуру навчальної діяльності студентів 1-5 курсів вищих навчальних закладів визначила, що суттєві зміни в компонентах психологічної структури навчальної діяльності на другому та четвертому курсах підтверджують положення про етапи кризи навчальної діяльності та положення про специфіку структури навчально-академічної та навчально-професійної діяльності. Варто зважати на ці висновки, здійснюючи активацію процесів мотивації пізнавальної діяльності студентів у напрямі підсилення інтенсифікаційних впливів на навчальну діяльність.

Якщо тлумачити дидактичну інтенсифікацію 3 погляду системно-діяльнісного підходу, стає очевидним, що її прикметними властивостями є здатність суб’єктів навчання до самоорганізації та саморегуляції.

Взаємозумовленість самоорганізації та саморегуляції визначає існування будь-якої системи. Саморегуляція забезпечує її цілісність, стійке функціонування, зберігає внутрішню рівновагу в умовах зовнішніх впливів. Самоорганізація забезпечує зовнішній відбір та накопичення інформації, що підвищують рівень організації структури та відбивають ії змістову здатність, себто відбивають функціональні можливості. Наявність саморегуляції та самоорганізації дозволяє говорити про можливість здійснення студентом інтенсифікації навчальної діяльності- досягнення позитивного результату за рахунок самостійного визначення студентом обсягу (порції) навчального матеріалу, самостійного вибору інформаційних джерел, вибору темпів, самостійного регулювання часових витрат.

Дидактичне новоутворення студентського віку- самоінтенсифікація навчальної діяльності - є своєрідним підсумком зовнішніх процесів дидактичної інтенсифікації, що розгорталися в єдності та тісних взаємозв'язках, та внутрішніх процесів самовдосконалення студента в навчальній діяльності. Окрім того, самоінтенсифікація навчальної діяльності - це внутрішній критерій ефективності дидактичної інтенсифікації. А до зовнішніх критеріїв дидактичної інтенсифікації навчальної діяльності студентів варто віднести:

- ступінь адаптації випускника вищого навчального закладу до професійної діяльності та до умов соціально-професійного оточення;

- темпи зростання процесів самоосвіти як пролонгований ефект дидактичної інтенсифікації навчальної діяльності;

- високий рівень професійної майстерності та професіоналізму; 
- стійка готовність продовжувати професійно-самоосвітню діяльність, підвищувати кваліфікаційний рівень, продовжувати навчання на більш високому рівні складності.

Отже, можна дійти висновків про те, що методичним інструментарієм інтенсифікації навчальної діяльності $€$ розроблення електронних навчальних посібників, застосування програм з перероблення інформації, використання ресурсів програмованого контролю, комп’ютерних методичних посібників, засобів індивідуального та групового консультування on-line, а самоінтенсифікація навчальної діяльності - є своєрідним підсумком зовнішніх процесів дидактичної інтенсифікації.

\section{Література}

1. Атанов Г. А. Возрождение дидактики - залог развития высшей школы / Григорий Атанов. - Донецк, 2003. - 180 с. 2. Кириченко О. Перспективи інноваційноінтелектуального розвитку України / О. Кириченко, Ю. Неговська // Вища школа. - 2011. № 3. - С. 36-46. 2. Кожемяко И. Л. Активизация познавательно-профессиональной деятельности студентов посредством мультимедиа технологий: дисс. на соискание ученой степени канд. пед. наук : 10.00.08. / Кожемяко Ирина Леонидовна. - Кемерово, 2007. - 267 с. 3. Кузьмінський А. І. Педагогіка вищої школи: [навч. посіб.]/ Анатолій Іванович Кузьмінський. - Київ : Знання, 2005. - 486 с. 4. Подоляк Л. Г. Психологія вищої школи : [підручник] / Л. Г. Подоляк, В. І. Юрченко. - Київ : Каравела, 2008. - 352 с. 5. Postman N. Technopoly: the Surrender of Culture to Technology / N. Postman. - 1992. - 69 p.

УДК $378.147(07)+371: 811$

Тетяна Мішеніна

\section{ОРГАНІЗАЦІЯ РОБОТИ СТУДЕНТІВ ФІЛОЛОГІЧНИХ СПЕЦІАЛЬНОСТЕЙ 3 НЕВІДМІНЮВАНИМИ ІМЕННИКАМИ В УКРАЇНСЬКІЙ МОВІ: ПРОБЛЕМНИЙ ПІДХІД}

Мішеніна Т. М. Організація роботи студентів філологічних спеціальностей 3 невідмінюваними іменниками в українській мові: проблемний підхід.

У статті розкрито зміст організації роботи студентів філологічних спеціальностей 3 невідмінюваними іменниками в українській мові на основі проблемного підходу, застосування якого сприятиме розв'язанню дидактичного, практичного, розвивального i контрольного завдань у процесі підготовки майбутніх учителів філологічних спеціальностей. Розроблено систему проблемнихзавдань, спрямованих на розв’язання проблеми сучасної україністики: лексико-семантичного і граматичного освоєння невідмінюваних іменників на сучасному етапі функціонування української мови.

Ключові слова: студенти філологічних спеціальностей, проблемний підхід, проблемна ситуація, семантико-граматичне засвоєння лексем, невідмінювані іменники.

Мишенина Т. М. Организация работы студентов филологических специальностей с несклоняемыми существительными в украинском языке: проблемный подход.

В статье раскрыта сущность организации работы студентов филологических специальностей с несклоняемыми существительными в украинском языке на основе проблемного подхода, применение которого будет способствовать решению дидактического, практического, развивающего и контрольного заданий в процессе подготовки будущих учителей филологических специальностей. Разработана система проблемных заданий, направленных на решение проблемы современной украинистики: лексико-семантического и 